2018

\title{
What is our role in moving the conversation forward?
}

\author{
Nola T. Radford \\ University of TN Health Science Center, ntradf@gmail.com \\ Jerry K. Hoepner \\ University of Wisconsin - Eau Claire, jerry@tlcsdjournal.com
}

DOI: doi.org/10.30707/TLCSD2.3Radford2

Follow this and additional works at: https://ir.library.illinoisstate.edu/tlcsd

\section{Recommended Citation}

Radford, Nola T. and Hoepner, Jerry K. (2018) "What is our role in moving the conversation forward?," Teaching and Learning in Communication Sciences \& Disorders: Vol. 2: Iss. 3, Article 7. DOI: doi.org/10.30707/TLCSD2.3Radford2

Available at: https://ir.library.illinoisstate.edu/tlcsd/vol2/iss3/7

This Reflection on SoTL is brought to you for free and open access by ISU ReD: Research and eData. It has been accepted for inclusion in Teaching and Learning in Communication Sciences \& Disorders by an authorized editor of ISU ReD: Research and eData. For more information, please contact ISUReD@ilstu.edu. 


\title{
What is our role in moving the conversation forward?
}

\begin{abstract}
What is our role in moving the conversation forward? A word from the guest editor and co-editor. Introduction to the Multicultural Special Topics Issue.
\end{abstract}

\section{Keywords}

Multicultural, SoTL, inclusion 
Since 1997, the American Speech-Language and Hearing Association (ASHA, 2017) has required instruction of multicultural/multilingual issues for the credentialing of speech-language pathologists (SLP) and audiologists (AUD). This requirement was motivated by a need to address the quality and appropriateness of training for speech-language-hearing professionals and the subsequent services provided to the public. This was a noble and empathic response of a profession whose core mission is to meet the communication needs of people. Yet, the professions of AUD and SLP continue to lack a common teaching philosophy, which has contributed to inconsistencies in the preparation of the next generation of speech and hearing professionals. Suggestions for unifying instructional pedagogies throughout the discipline have been identified by a number of Scholarship of Teaching and Learning (SoTL) authors. Several key pedagogical issues identified by one such team, Horton-Ikard, Munoz, Thomas-Tate and Keller-Bell (2009) still warrant further investigation. Three issues will be highlighted here, as they relate specifically to the papers in this special issue. We hope our summary of these key issues serves as a lens for examining articles in this special issue with a constructive, open mindset.

First, the papers in this volume represent works that illustrate the need for greater attention to teaching philosophy. The authors are commended for examining application of social justice issues to multicultural issues. A potential danger of this approach, acknowledged by the authors, is the unintentional introduction of politically charged papers which may perpetuate bias. Of course, all research is subject to the views of the researcher and unintended extensions to political ideals can be diffused by an acknowledgement that their research represents systematic results through the authors' lens. As such, authors of these articles have acknowledged their inherent perspectives and used techniques like member checking to minimize these risks.

A second challenging issue is the notion of multiculturalism, which is still a relatively new concept and newer still in application in AUD and SLP. Multiculturalism is a multidisciplinary field that has relied upon existing pedagogical practices of education and the medical professions to develop approaches for teaching and learning. As such, there has been limited attempts to systematically examine if those approaches are effective in teaching about multicultural issues or if different approaches may be warranted. Contributors to the current volume have applied systematic, scientific inquiry across qualitative, quantitative, and mixed methodologies in an attempt to address this gap. Readers are encouraged to examine Johnson and Onwuegbuzie (2004) and/or Creswell and Creswell (2017), which identify the value in drawing upon both methodologies. We always encourage readers to examine new findings in the context of related work.

Lastly, a final issue which the papers in the volume both represent and explore is the notion of inclusion and how best to prepare speech-language-hearing professionals to serve an increasingly diverse population. Authors rightly address inclusion and the need to recruit individuals of diverse backgrounds to serve. Indeed, inclusion is an action worthy of deliberate scientific inquiry, if we are to be consistent with the guiding principles of ASHA (2017) and the Council on Academic Accreditation in Audiology and Speech-Language Pathology 2017). We hope to have served to move the conversation forward by thoughtfully and carefully considering the submissions to this special issue. 
One of the most positive outcomes of this special issue is the bringing together of diverse perspectives. Even though all of the contributors to this special issue are focused on the topics of cultural diversity and multicultural issues, they each carry with them their own perspectives and interpretations. While the editors may not endorse all of the ideals shared, we do endorse learning from each of these perspectives. It is a good thing to hear from a variety of perspectives and recognize our own biases, reflect upon the tension between bias and value, and consider how we may learn from and respect our differences. The purpose of this special issue is to address and extend empirical evidence for instructional techniques and content in the context of the SoTL. Thus, our main focus is the preparation of future practitioners through curricular and extracurricular learning from a SoTL framework. While that is true, we ARE training the next generation of students, and attempting to examine notions of cultural competence and how to apply notions of sensitivity, inclusion, and respect broadly in the discipline.

With the aforementioned considerations in mind, we are pleased to introduce the articles in this special issue.

- Our guest editor, Nola Radford, contributed a reflection on her own experiences and parallels within the history of our profession, relating the relevance of history and the perspectives of individual stakeholders to the education of future communication sciences and disorders practitioners; this is our lead article: "Multiculturalism to Diversity: Implications from an SLP's Journey."

- Sarah Ginsberg contributed a pair of articles related to practices that support recruitment and retention of diverse students, particularly identifying factors that support success: "Increasing African American Student Success in SpeechLanguage Pathology Programs" and "Stories of Success: African American Speech-Language Pathologists' Academic Resilience."

- Crystal Randolph and Janet Bradshaw contributed an investigation of multicultural counseling, including perceptions of when and where training and learning of this skill takes place: "An Exploratory Study of Speech-Language Pathologists' Perceptions of Multicultural Counseling in Communication Sciences and Disorders."

- Audrey Farrugia-Bernard shared an investigation that considers preparation of SLP students for working in urban environments with culturally and linguistically diverse clients: "A Qualitative Exploration of the Preparation Practices of SLPs Practicing in Urban Schools with Culturally and Linguistically Diverse Students."

- Akiko Fuse and Michael Bergen contributed findings of a survey of alumni from an urban university, addressing factors that contribute to persistence and success: "The Role of Support Systems for Success of Underrepresented Students in Communication Sciences and Disorders."

Finally, we invite you to remain in the conversation. We hope that this issue serves as a springboard for further empirical contributions and dialogue.

Collaboratively,

Nola Radford, Guest Editor and Jerry Hoepner, Issue Co-editor 


\section{References}

American Speech-Language and Hearing Association (2017). Council on Academic Accreditation. Chapter II: Mission and Principles of the CAA. Retrieved from https://caa.asha.org/wp-content/uploads/Accreditation-Handbook.pdf

Council on Academic Accreditation in Audiology and Speech-Language Pathology. (2017). Standards for accreditation of graduate education programs in audiology and speechlanguage pathology (2017). Retrieved 3/25/2018 from http://caa.asha.org/wpcontent/uploads/Accreditation-Standards-for-GraduatePrograms.pdf

Creswell, J. W., \& Creswell, J. D. (2017). Research design: Qualitative, quantitative, and mixed methods approaches. Thousand Oaks, CA: Sage publications.

Horton-Ikard, R., Munoz, M. L., Thomas-Tate, S., \& Keller-Bell, Y. (2009). Establishing a pedagogical framework for a multicultural course in Communication Sciences and Disorders. American Journal of Speech-Language Pathology, 18, 192-206.

Johnson, R. B., \& Onwuegbuzie, A. J. (2004). Mixed methods research: A research paradigm whose time has come. Educational researcher, 33(7), 14-26. 